\title{
Current Approach in Radiation Therapy for Prostate Cancer
}

\author{
(i) Ilknur Alsan Çetin
}

Marmara University Faculty of Medicine, Department of Radiation Oncology, Istanbul, Turkey

\begin{abstract}
Prostate cancer is one of the most common malignancies in men. Radiotherapy is one of the main treatment modalities in the treatment of prostate cancer. The reflection of technological advances in the field of radiation oncology enables the safe application of higher doses of radiotherapy in the treatment of prostate cancer. In addition, improvements in normal tissue preservation are reflected in patients' quality of life. Radiotherapy can be applied in all stages of prostate cancer and postoperative radiotherapy can be applied in appropriate indication. Side effects are expected to be observed more in patients undergoing postoperative radiotherapy. The treatment decision should be based on personal preference after informing the patient about the advantages and disadvantages of each treatment approach.
\end{abstract}

Keywords: Prostate cancer, radiotherapy, treatment

\section{Introduction}

Prostate cancer (PC) is one of the most common malignancies in men. Radical prostatectomy (RP), external beam radiotherapy (EBRT), brachytherapy (BCT) are different options that can be applied in patients with limited disease. Surgery and radiotherapy (RT) are considered standard in the treatment of localized PC. Treatment decision should be made with the patient after a multidisciplinary evaluation of the patient's age, performance status, accompanying diseases, life expectancy and possible side effects of the treatment. In addition to life expectancy, quality of life is also important in patients. The patient should also be informed that RT may be needed after surgery and that side effects may increase.

The reflection of technological developments in Radiation Oncology has enabled increased sensitivity in determining tumor sites, to reflect these identified areas to treatment at high accuracy rate [Image-guided Radiotherapy (IGRT)], to decrease margins given to tumors (Intensity-Modulated RadiotherapyIMRT), and thus to preserve more normal tissue (1). As a result of the increase in sensitivity and accuracy, the increase in doses administered and the application of high doses within a short period of time [Stereotactic Body Radiotherapy (SBRT)] is possible and the treatment times are shortened. Thanks to all these developments, both high tumor control and increased life expectancy, as well as a decrease in normal tissue toxicity of patients and the resulting increase in quality of life have been achieved.
The RT used in PC is EBRT and BCT. Current approaches in RT techniques are IMRT and SBRT. The form of treatment, dose and hormone therapy (HT) vary according to the risks and stages of PC. Curative RT of localized PC is administered in doses between 74-81 Gy for 7-9 weeks with conventional fractions (1.8-2 Gy/day) as standard and 5 days per week. It is possible to apply higher doses to the tumor with fewer side effects in parallel with technological developments in imaging methods and computer software.

Very Low Risk PC; T1C, grade group 1 (GS 6), prostate specific antigen (PSA) $<10,1$ or 2 quadrant positivities and $\leq 50 \%$ for each quadrant positivity and PSA density $\leq 0.15 \mathrm{ng} / \mathrm{mL}$. Magnetic resonance imaging and genomic tests may be performed to rule out high-grade disease in patients younger than 62 years. Active follow-up is often recommended except this group of patients.

Low Risk PC; T1c/T2a, grade group 1 (GS 6), PSA $<10$. Treatment options are ERT and BCT. EBRT can be applied as standard fractionation (2 Gy per day) with 78-80 Gy, as Hypofractionated RT (HRT); 70 Gy (2.5 Gy per day), 60 Gy (3 Gy per day) or as SBRT; 36-40 Gy (7.25-8 Gy per day). BCT can be applied as Low-dose-rate (LDR): I-125, Pd-103, Cs-131 (with permanent source placement) or High-dose-rate (HDR) (with Ir-192 catheters, 4 times). D'Amico et al. (2) showed that the results of treatment with RP, EBRT and BCT were similar in patients with low-risk PC. BCT studies showed results ranging from $95 \%$ to $85 \%$ in $5-10$-year PSA controls in different series $(3,4,5,6)$. In the Spirit trial, BCT and RP were compared in

Cite this article as: Çetin IA. Current Approach in Radiation Therapy for Prostate Cancer. Bull Urooncol 2020;19(2):49-55 
terms of quality of life and there were statistically significant less urinary leakage and better sexual outcomes in BCT (7). Donovan et al. (8) compared quality of life results between RP and EBRT in the "Prostate Testing for Cancer and Treatment" (Protect) trial and showed that RP had better results in terms of intestinal functions and nocturia, while EBRT had better results in terms of incontinence and erectile dysfunction.

HRT (daily fraction dose 2.4-4 Gy, total treatment duration 4-6 weeks). The total duration of treatment for PC due to its radiobiological characteristics can be shortened by increasing the fraction dose, i.e. hypofractionation. The results of studies comparing moderate hypofractionation with standard fractionation were found to be similar (Table 1). The meta-analysis showed similar results except for higher acute gastrointestinal $(\mathrm{Gl})$ side effects with conventional EBRT (16). Therefore, moderately HRT is recommended in low and moderate risk PC (17). In Ultra HRT (SBRT), fraction doses between 4-10 Gy per day are generally applied in $\leq 5$ fractions with a total dose of 35-50 Gy. The studies are shown in Table 2.

SBRT can cause more side effects than moderately HRT. The Swedish study, a phase III randomized study, compared 42.7 Gy (6.1 Gy per day) SBRT with 78 Gy (2 Gy per day) conventional

\begin{tabular}{|c|c|c|c|c|c|c|c|c|c|c|c|}
\hline Trial & $n$ & \begin{tabular}{|l|} 
Trial \\
design
\end{tabular} & $\begin{array}{l}\text { Trial } \\
\text { arms }\end{array}$ & $\begin{array}{l}\text { Risk } \\
\text { groups }\end{array}$ & HT & \begin{tabular}{|l|} 
Median \\
follow-up
\end{tabular} & $\begin{array}{l}\text { Cancer } \\
\text { control }\end{array}$ & $\begin{array}{l}\text { Acute } \\
\text { GU SE }\end{array}$ & Acute GI SE & $\begin{array}{l}\text { Late } \\
\text { GU SE }\end{array}$ & $\begin{array}{l}\text { Late GI } \\
\text { SE }\end{array}$ \\
\hline $\begin{array}{l}\text { Dearnaley et al. } \\
\text { (9) }\end{array}$ & 3216 & $\begin{array}{l}\text { Multicenter } \\
\text { Non-inferiority } \\
\text { Biochemical or } \\
\text { clinical failure } \\
\text { rate }\end{array}$ & $\begin{array}{l}74 \text { Gy (2 Gy) } \\
60 \text { Gy (3 Gy) } \\
57 \text { Gy (3 Gy) }\end{array}$ & $\begin{array}{l}15 \% \text { Low } \\
73 \% \text { Intermediate } \\
12 \% \text { High }\end{array}$ & $\begin{array}{l}97 \% \\
3-6 \\
\text { months }\end{array}$ & 5.2 years & $\begin{array}{l}60 \text { Gy/74 Gy } \\
\text { same } \\
57 \text { Gy was } \\
\text { worse than } \\
74 \text { Gy }\end{array}$ & Similar & \begin{tabular}{l|} 
Increased \\
risk with \\
hypofractionation \\
$25 \% / 38 \%$
\end{tabular} & Similar & Similar \\
\hline $\begin{array}{l}\text { Catton et al. } \\
\text { (10) }\end{array}$ & 608 & $\begin{array}{l}\text { Multicenter } \\
\text { Non-inferiority } \\
\text { Biochemical or } \\
\text { clinical failure rate }\end{array}$ & $\begin{array}{l}78 \text { Gy (2 Gy) } \\
60 \text { Gy (3 Gy) }\end{array}$ & Intermediate & No & 6 years & $\begin{array}{l}\text { Hypofractionation } \\
\text { was non-inferior }\end{array}$ & Similar & $\begin{array}{l}\text { Increased risk } \\
\text { with EBRT } \\
10 \% / 16 \%\end{array}$ & Similar & $\begin{array}{l}\text { Reduced } \\
\text { risk with } \\
\text { hypofractionation } \\
11 \% / 7 \%\end{array}$ \\
\hline $\begin{array}{l}\text { Lee et al. } \\
\text { (11) }\end{array}$ & 1115 & $\begin{array}{l}\text { Multicenter } \\
\text { Disease-free } \\
\text { survival }\end{array}$ & $\begin{array}{l}7380 \text { cGy (1.8 Gy) } \\
70 \text { Gy (2.5 Gy) }\end{array}$ & Low & No & 5.8 years & $\begin{array}{l}\text { Hypofractionation } \\
\text { was non-inferior }\end{array}$ & Similar & Similar & $\begin{array}{l}\text { Increased } \\
\text { risk } \\
\text { with EBRT } \\
23 \% / 30 \%\end{array}$ & $\begin{array}{l}\text { Increased } \\
\text { risk with } \\
\text { EBRT } \\
14 \% / 22 \%\end{array}$ \\
\hline $\begin{array}{l}\text { Incrocci et al. } \\
(12)\end{array}$ & 820 & $\begin{array}{l}\text { Çok merkezli } \\
\text { Recurrence-free } \\
\text { survival }\end{array}$ & $\begin{array}{l}78 \text { Gy (2Gy) /78 Gy } \\
6460 \text { cGy (3.4Gy) / } \\
87 \text { Gy }\end{array}$ & $\begin{array}{l}\text { 26\% Intermediate } \\
74 \% \text { High }\end{array}$ & $67 \%$ & 5 years & $\begin{array}{l}\text { Non-significant } \\
\text { difference }\end{array}$ & Similar & $\begin{array}{l}\text { Increased } \\
\text { risk with } \\
\text { BRT } \\
31 \% / 42 \% \\
\end{array}$ & $39 \% / 41 \%$ & $18 \% / 22 \%$ \\
\hline $\begin{array}{l}\text { Shaikh et al. } \\
\text { (13) }\end{array}$ & 303 & $\begin{array}{l}\text { Single center } \\
\text { Biochemical } \\
\text { failure }\end{array}$ & $\begin{array}{l}76 \text { Gy (2 Gy) /76 Gy } \\
7020 \text { cGy (2.7Gy)/ } \\
84 \text { Gy }\end{array}$ & $\begin{array}{l}66 \% \text { Intermediate } \\
33 \% \text { High }\end{array}$ & $46 \%$ & 5.7 years & $\begin{array}{l}\text { Non-significant } \\
\text { difference }\end{array}$ & & & Similar & Similar \\
\hline $\begin{array}{l}\text { Hoffman et al. } \\
\text { (14) }\end{array}$ & 206 & $\begin{array}{l}\text { Single center } \\
\text { Disease-free } \\
\text { survival }\end{array}$ & $\begin{array}{l}7560 \text { cGy (1.8 Gy) } \\
\text { /71 Gy } \\
72 \text { Gy (2.4 Gy)/ } \\
84 \text { Gy }\end{array}$ & $\begin{array}{l}28 \% \text { Low } \\
71 \% \text { Intermediate }\end{array}$ & $\% 24$ & 8.4 years & $\begin{array}{l}\text { Hypofractionation } \\
\text { improved cancer } \\
\text { control }\end{array}$ & & & Similar & $\begin{array}{l}\text { Increased } \\
\text { trend } \\
5 \% / 13 \% \\
p=0.08\end{array}$ \\
\hline $\begin{array}{l}\text { Valeriani et al. } \\
\text { (15) }\end{array}$ & 168 & $\begin{array}{l}\text { Single center } \\
\text { Late toxicity }\end{array}$ & $\begin{array}{l}80 \text { Gy (2 Gy) } \\
62 \text { Gy (3.1 Gy) } \\
/ 81 \text { Gy }\end{array}$ & High & All & 9 years & $\begin{array}{l}\text { Non-significant } \\
\text { difference }\end{array}$ & Similar & $\begin{array}{l}\text { Increased } \\
\text { trend } 21 \% / 35 \% \\
\mathrm{p}=0.07\end{array}$ & Similar & Similar \\
\hline
\end{tabular}

\begin{tabular}{|c|c|c|c|c|c|c|c|c|c|c|c|}
\hline \multirow[t]{2}{*}{ Trial } & \multirow[t]{2}{*}{$\mathbf{n}$} & \multirow{2}{*}{$\begin{array}{l}\text { Median } \\
\text { follow-up } \\
\text { (years) }\end{array}$} & \multirow[t]{2}{*}{ Dose } & \multirow[t]{2}{*}{ EQD2 } & \multirow[t]{2}{*}{ GS 6} & \multicolumn{2}{|c|}{ Acute G3+ } & \multicolumn{2}{|c|}{ Late G3+ } & & \multirow{2}{*}{$\begin{array}{l}\text { 5-year } \\
\text { BDFS }\end{array}$} \\
\hline & & & & & & GU & GI & GU & GI & ED & \\
\hline Pham et al. 2010 (18) (Abstract) & 40 & $5 y ı 1$ & 34 Gy (5 frc) & 82 Gy & $100 \%$ & $2 \%$ & $0 \%$ & $3 \%$ & $0 \%$ & $50 \%$ & $93 \%$ \\
\hline Kupelian et al. 2013 (19) (Abstract) & 135 & 5 & 35/40 Gy (4-5 frc) & 8650-11060 cGy & $80 \%$ & NR & NR & NR & NR & NR & $97 \%$ \\
\hline Mantz, 2014 (20) & 102 & $>5$ & 40 Gy (5 frc) & 11060 cGy & $69 \%$ & $2 \%$ & $0 \%$ & NR & $0 \%$ & NR & $100 \%$ \\
\hline Hannan et al. 2016 (21) & 91 & 4.5 & 45-50 Gy (5 frc) & 13800-16800 cGy & $47 \%$ & $0 \%$ & $2 \%$ & $5 \%$ & $7 \%$ & $26 \%$ & $99 \%$ \\
\hline Musunuru et al. 2016 (22) & 84 & 6.2 & 35 Gy (5 frc) & 8650 cGy & $100 \%$ & $1 \%$ & $0 \%$ & $0 \%$ & $1 \%$ & $43 \%$ & $97 \%$ \\
\hline Zimmerman et al. 2016 (23) & 80 & 6.9 & 45 Gy (9 frc) & 8470 cGy & $100 \%$ & NR & NR & $4 \%$ & $13 \%$ & NR & $96 \%$ \\
\hline Total & 532 & & & & $80 \%$ & $1.2 \%$ & $0.6 \%$ & $3 \%$ & $2.6 \%$ & $37 \%$ & $98 \%$ \\
\hline
\end{tabular}


RT in patients with intermediate and high risk PC. Biochemical relapse-free survival rate $(83.8 \%$ vs. $83.7 \%)$, late urinary side effects (3.5\% vs. $2.5 \%)$ and rectal (2.3\% vs. $1.3 \%)$ side effects were similar in 5-year follow-up (24). The PACE B randomized study compared 36.5 Gy (7.25 Gy per day) SBRT and 78 Gy (2 Gy per day) EBRT in 858 patients with low and intermediate risk $P C$. No difference was detected in terms of acute side effects (25). A meta-analysis of 6116 patients showed that SBRT increased biochemical control $(p=0.018)$ but were associated with more grade 3 or above genitourinary (GU) side effects $(p=0.014)(26)$. In light of the studies, SBRT may also be recommended, especially for low-risk patients.

Intermediate Risk PC; Good intermediate risk: $<50 \%$ biopsy positivity (presence of only 1 moderate risk factor T2b/c or GS $(3+4)$ or PSA:10-20 ng/mL). Good intermediate risk tends to be treated like a low risk group. BCT, EBRT or moderately HRT can be performed. Poor intermediate risk: GS (4+3), contains $\geq 50 \%$ biopsy positivity or many intermediate risk factors. Short term (4-6 months) HT with EBRT, BCT boost with EBRT (and/ or short term HT) can be applied. Studies on dose increase in intermediate risk PC are going on. In the GETUG-14 trial, 377 patients with intermediate risk PC were treated with 80 Gy EBRT either alone or in combination with HT for 4 months. Five-year biochemical failure rates were $21 \%$ and $10 \%$ in the groups $(p=0.02)$ and no difference was detected in terms of toxicity (27). In the ASCENDE-RT trial, medium and high risk patients were either given dose-escalated EBRT boost to 78 Gy (2 Gy per day) or LDR BCT (115 Gy I125) boost. Biochemical failure rates in the $B C T$ arm were found to be statistically significantly 2 times better for medium and high risk patients (28).

High Risk PC; EBRT and HT (1.5-3 years) or EBRT, BCT boost and $\mathrm{HT}$ (1-3 years) are recommended. In 3 randomized studies, biochemical recurrence-free survival was found to be statistically significantly higher with dose-escalating EBRT and BCT $(28,29,30)$.

\begin{tabular}{|c|c|c|c|c|}
\hline Trials & Risk groups & Trial arms & 5-year results & 10-year results \\
\hline \multicolumn{5}{|l|}{ Standard dose EBRT } \\
\hline D'Amico et al. (31) & Intermediate/high-risk PC & $\begin{array}{l}\text { Arm 1 }=\text { EBRT } \\
\text { Arm 2= EBRT }+\mathrm{HT} \text { ( } 6 \text { months) }\end{array}$ & $\begin{array}{l}\mathrm{CSS}=94 / 100 \\
\mathrm{OS}=77 / 88 \\
\mathrm{BPFS}=55 / 79\end{array}$ & $\begin{array}{l}\text { OS }=61 / 74(8 \text { years }) \\
\text { DSS }=84 / 78 \text { ( } 8 \text { years }) \\
\text { OS }=28 / 35 \text { NS }(15 \text { years })\end{array}$ \\
\hline Pilepich et al. (32) & High-risk PC & $\begin{array}{l}\text { Arm 1 }=\text { EBRT } \\
\text { Arm 2= EBRT }+\mathrm{HT}\end{array}$ & $\begin{array}{l}\mathrm{BRFS}=21 / 55 \\
\mathrm{DM}=29 / 15 \\
\mathrm{CSS}=87 / 91 \\
\mathrm{OS}=71 / 76\end{array}$ & $\begin{array}{ll}\mathrm{DM}=39 / 24 & \mathrm{CSS}=78 / 84 \\
\mathrm{OS}=39 / 49 & \mathrm{BPFS}=9 / 31 \\
\mathrm{LF}=38 / 23 & \mathrm{DSS}=78 / 84\end{array}$ \\
\hline Bolla et al. (33) & High-risk PC & $\begin{array}{l}\text { Arm 1 }=\text { EBRT } \\
\text { Arm 2= EBRT }+\mathrm{HT}(3 \text { years })\end{array}$ & $\begin{array}{l}\mathrm{CSS}=79 / 94 \\
\mathrm{BPFS}=45 / 76 \\
\mathrm{DM}=29 / 10 \\
\mathrm{OS}=62 / 78 \\
\mathrm{LF}=1 / 7\end{array}$ & $\begin{array}{l}\mathrm{DFS}=23 / 48 \\
\mathrm{OS}=40 / 58 \\
\mathrm{CSS}=70 / 90 \\
\mathrm{DSS}=10 / 30\end{array}$ \\
\hline Pilepich et al. (34) & High-risk PC & $\begin{array}{l}\text { Arm 1= EBRT } \\
\text { Arm 2=EBRT+ HT (4 months) }\end{array}$ & $\begin{array}{l}\mathrm{BRFS}=10 / 28 \\
\mathrm{CSS}=80 / 85 \\
\mathrm{DM}=39 / 29 \\
\mathrm{OS}=68 / 72 \mathrm{NS}\end{array}$ & $\begin{array}{l}\mathrm{OS}=34 / 43 \mathrm{NS} \\
\mathrm{BRFS}=80 / 65 \\
\mathrm{DM}=27 / 35 \\
\mathrm{CSS}=64 / 77 \\
\mathrm{DSS}=23 / 36\end{array}$ \\
\hline Jones et al. (35) & $\begin{array}{l}\text { Low/intermediate/high-risk } \\
\text { PC }\end{array}$ & $\begin{array}{l}\text { Arm 1= EBRT } \\
\text { Arm 2= EBRT }+\mathrm{HT} \text { (4 months) }\end{array}$ & $\begin{array}{l}\mathrm{LF}=39 / 21 \\
(2 \text { years })\end{array}$ & $\begin{array}{l}\mathrm{BRFS}=59 / 47 \\
\mathrm{OS}=57 / 62 \\
\mathrm{CSS}=92 / 96 \\
\mathrm{DM}=8 / 6\end{array}$ \\
\hline \multicolumn{5}{|l|}{ Dose-escalating EBRT } \\
\hline Bolla et al. (36) & Intermediate/high-risk PC & $\begin{array}{l}\text { Arm } 1=\text { EBRT }(70,74,78 \mathrm{~Gy}) \\
\text { Arm } 2=\text { EBRT }(70,74,78 \mathrm{~Gy})+\mathrm{HT} \\
(6 \text { months })\end{array}$ & $\begin{array}{l}\mathrm{BRFS}=70 / 83 \\
\mathrm{DM}=4 / 8 \mathrm{NS} \\
\mathrm{OS}=88 / 91 \mathrm{NS}\end{array}$ & NR \\
\hline Nabid et al. (37) & Intermediate-risk PC & $\begin{array}{l}\text { Arm 1= EBRT (70 Gy) + HT (6 months) } \\
\text { Arm 2=EBRT (76 Gy) + HT (6 months) } \\
\text { Arm 3 = EBRT (76 Gy) }\end{array}$ & $\begin{array}{l}\mathrm{BF}=7 / 2 / 14^{*} \\
\mathrm{DFS}=93 / 97 / 86^{*} \\
\mathrm{OS}=90 / 94 / 91 \mathrm{NS} \\
*=\mathrm{NS} \text { between arms } 1-2\end{array}$ & $\begin{array}{l}\mathrm{BF}=22 / 22 / 33^{*} \\
\mathrm{DFS}=78 / 78 / 67^{*} \\
\mathrm{OS}=63 / 72 / 75 \mathrm{NS} \\
{ }^{*}=\mathrm{NS} \text { between arms } 1-2\end{array}$ \\
\hline Dubray et al. (27) & Intermediate-risk PC & $\begin{array}{l}\text { Arm } 1=\text { EBRT (80 Gy) } \\
\text { Arm } 2=\text { EBRT (80 Gy) + HT (4 years) }\end{array}$ & $\begin{array}{l}\mathrm{BRFS}=76 / 84 \\
\mathrm{OS}=94 / 93 \mathrm{NS}\end{array}$ & NR \\
\hline Dearnaley et al. (38) & $\begin{array}{l}\text { Low/intermediate/high-risk } \\
\text { PC }\end{array}$ & $\begin{array}{l}\text { Arm } 1=\text { EBRT (64 Gy) }+ \text { HT (3-6 months) } \\
\text { Arm } 2=\text { EBRT (74 Gy) + HT (3-6 months) }\end{array}$ & - & $\begin{array}{l}\mathrm{BPFS}=43 / 55 \\
\mathrm{OS}=71 / 71^{*}\end{array}$ \\
\hline $\begin{array}{l}\text { EBRT: External beam r } \\
\text { free survival, CSS: Ca } \\
\text { cancer, BPFS: Biochen }\end{array}$ & $\begin{array}{l}\text { y, HT: Hormone the } \\
\text { survival, NS: Not }\end{array}$ & $\begin{array}{l}\text { erall survival, DM: Di } \\
\text { DSS: Disease-specific }\end{array}$ & ilure, NR: Not re & $\begin{array}{l}\text { FS: Biochemical recurrence- } \\
\text { emical failure, PC: Prostate }\end{array}$ \\
\hline
\end{tabular}


In the ASCENDE-RT trial, 398 patients were randomized to a standard arm with 12 months of androgen deprivation therapy, pelvic irradiation to $46 \mathrm{~Gy}$, followed by a dose-escalated EBRT boost to $78 \mathrm{~Gy}$, or an experimental arm that substituted a LDRBCT boost (28). Nine-year biochemical recurrence-free survival was significantly better in the BCT boost arm $(p=0.004)$. In addition, grade $\geq$ III urinary toxicity was found lower in the BCT boost arm (19\% vs. 5\%, $\mathrm{p}<0.001)$. In numerous phase III randomized trials, neoadjuvant and adjuvant HT have been proven to be beneficial in combination with EBRT ( $\geq 70 \mathrm{~Gy}$ ) in the treatment of high risk PC $(31,32,33,34,35)$, (Table 3).

Adding HT has significantly reduced the risk of biochemical failure, clinical progress, local recurrence and distant metastasis without increasing the risk of death due to cardiac problems, GU toxicity and GI toxicity. A meta-analysis has shown that adding HT to ERT reduces the risk of death from PC by $24 \%$ and the risk of death from other causes by $14 \%$ (39). Numerous randomized studies have shown that dose-escalating EBRT ( $\geq 74$ Gy) improves biochemical outcomes compared with conventional doses $(40,41)$. The EORTC 22991 trial showed that adding short-term HT (ST-HT) to dose-escalating ERT improved 5-year biochemical progression-free survival (BPFS)
(36). The results of other phase III dose-escalating-EBRT trials have shown that addition of ST-HT still provides a benefit in intermediate risk patients $(27,36)$. Adding ST-HT to doseescalating-EBRT in patients with intermediate risk PC improves BPFS and reduces distant metastasis, and PC-specific mortality (PCSM) (37). MRC RT01 showed that dose-escalation from 64 Gy to 74 Gy improved BPFS, even when both arms were given ST-HT (38). Long-term (LT)- HT is used in the treatment of patients with high risk PC (42).

This recommendation is largely based on EORTC 22961 and RTOG 9202 trials $(45,46)$. In both trials, it was shown that cancerspecific survival and overall survival were increased with LT-HT (28-36 months) compared to ST-HT (4-6 months) (Table 4).

DART01/05 trial, a trial comparing the duration of HT with Dose-escalating EBRT, found that LT-HT (28 months) improved biochemical control, distant metastasis-free survival and overall survival compared to ST-HT (4 months) (Table 4) (48). The PCS IV trial compared ST-HT (18 months) and LT-HT (36 months) and concluded that ST-HT was as effective as LT-HT and improved quality of life (49). The use of genomics in the future to find out which patients should be given personalized treatment is the topic on the agenda for high risk PC. Mahal et al. (50) showed

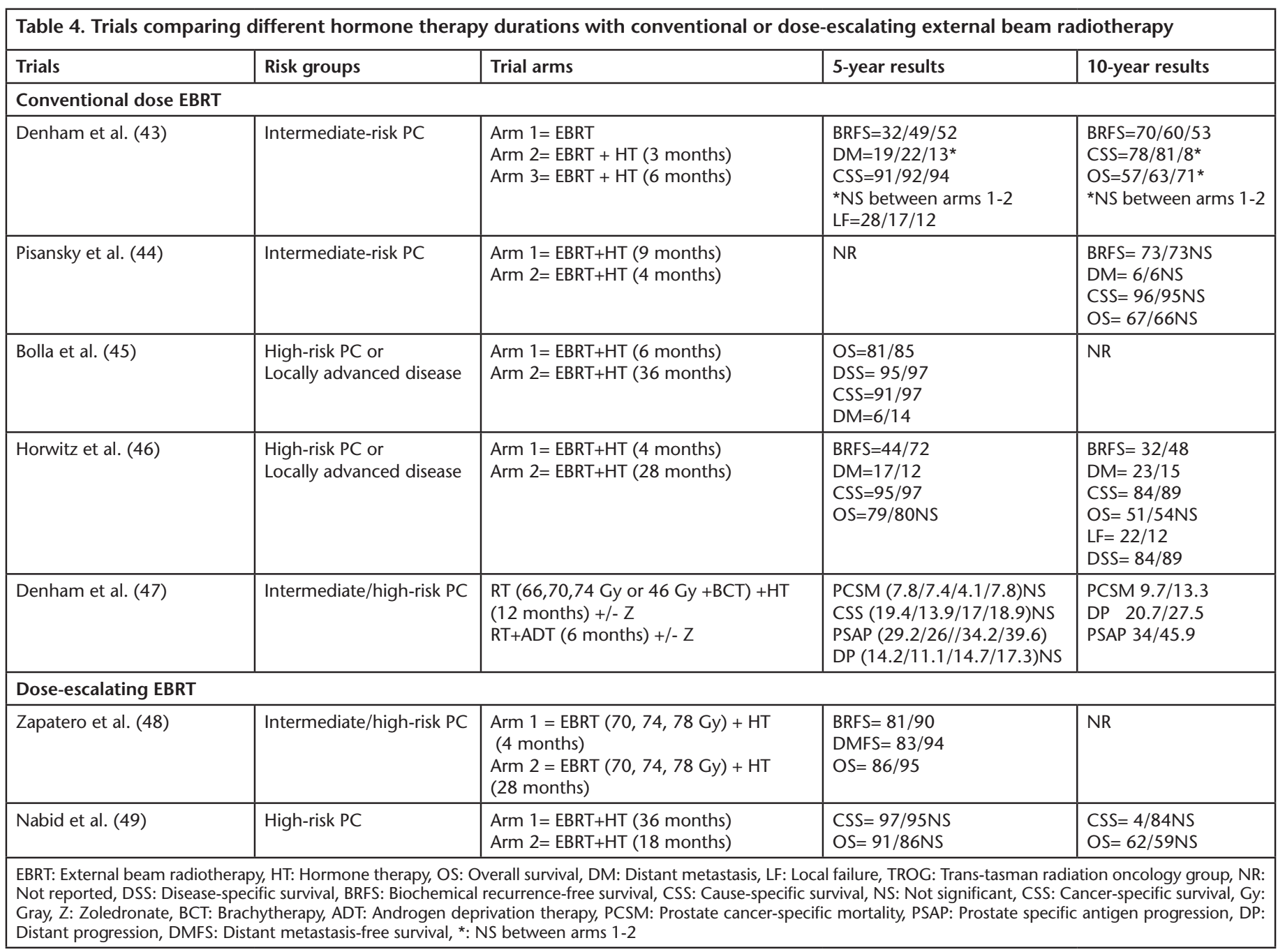


that there was a statistically significant relationship between the rate of metastasis and Decipher score $>0.6(p<0.001)$. The genomic risk group and the National Comprehensive Cancer Network risk group have been evaluated together and clinicalgenomic risk group classification has been established (51). In high risk patients; treatment schemes have been established: LT-HT and RT or ST-HT and RT in patients with low genomic risk and LT-HT and RT or ST-HT and RT with LT abirateron or LT apalutamide arms in patients with high genomic risk (NRG GU 1864 Clinical Trial).

Postoperative RT; Positive surgical margin is recommended in disease at level of pathological T3 or higher (52). In SWOG randomized trial, it was found that the addition of postoperative RT provided a survival advantage in patients with pT3 or positive surgical margin (53). Genomic classification can tell us about the timing of postoperative RT (54). The results of randomized trials (RADICALS-HT for its necessity and duration, RAVES-RT for its timing) on postoperative RT timing (early or early salvage) are expected. The 5-year results of the RAVES randomized trial were reported at ASTRO 2019. Starting adjuvant RT at 4-6 months was compared with early salvage RT when PSA was $\geq 0.2 \mathrm{ng} /$ $\mathrm{mL}$. Five-year results showed no difference in terms of BPFS and locoregional and distant metastasis free survival rates. In the RTOG 96-01 randomized trial, salvage RT and/or 2-year HT was compared with salvage RT alone in 771 patients who had PSA rising after RP in 13-year follow-up. Salvage RT and/or 2-year HT was associated with lower development of metastasis (11\% vs. $19 \%)$, lower PCSM (4.5\% vs. $10.1 \%)$ and longer overall survival ( $82 \%$ vs. $78 \%),(p<0.01, p=0.036$ and $p<0.001$, respectively). In subgroup analysis; this advantage was increased in those with PSA $>1.5 \mathrm{ng} / \mathrm{mL}$ and surgical margin positivity (55). In the GETUG/AFU-16 randomized trial, there was statistically significant difference between EBRT in combination with 6-month HT and EBRT alone in terms of 5-year BPFS (62.1\% vs. $79.6 \%, p<0.001$ and survival (56). After RP, 1107 patients with lymph node positivity were retrospectively evaluated. Eightyear cancer-specific mortality rates were statistically significantly lower in the postoperative RT and HT group than the HT alone group in patients with lymph node positivity $<4$ (57).

Oligometastasis PC; Ost et al. (58) compared the patients who were treated for metastasis and the patients who were not in a phase II randomized trial. Sixty two patients with $\leq 3$ bone or lymph node metastases were examined. BPFS and cancerspecific mortality were better in the group undergoing treatment for metastasis $(p=0.03)$. In the Stampede phase III randomized trial, 2061 patients with metastatic PC were evaluated. The addition of RT to the treatment of metastatic patients initially was found to increase disease-free survival and overall survival, especially in patients with low metastasis load $(p<0.0001$ and $\mathrm{p}=0.007$, respectively) (59). In the Horrad randomized trial, 432 patients with bone metastasis $(<5)$ were evaluated and the time to PSA progression was found to be longer $(p=0.02)$ in patients who received RT to prostate and bones, but there was no difference in terms of survival (60). Burdett et al. (61) showed in their meta-analysis that patients who received RT to prostate and $\mathrm{HT}$ had $7 \%$ longer 3-year survival compared with patients who took only HT in patients with less than 5 bone metastases. Fifty four patients were evaluated in the Oriole phase II trial.
The patients with 1-3 bone metastases ( $\leq 5 \mathrm{~cm}$ lesion) were randomly assigned to SBRT or observation arms. In the early 24 months early results, the time to progression-free survival was longer at the $6^{\text {th }}$ month.

Studies are going on the use of neoadjuvant or adjuvant chemotherapy, immunotherapy and next generation HT agents in combination with EBRT. In the RTOG 0521 randomized study, standard HT (2 years) and RT (72.0-75.6 Gy) arm was compared with RT, HT and docetaxel (adjuvant 6 cures after RT is completed) in 612 patients. In 6-year follow-up, general and disease-free survival rates significantly increased in favor of the docetaxel-added arm ( $p=0.03$ and $p=0.05$, respectively) (62).

Proton and heavy ion therapy can reduce the amount of radiation used in RT that goes beyond the target. However, more data are needed on this issue. There are ongoing studies.

\section{Conclusion}

It is possible to safely perform RT at all stages of PC. With advances in imaging methods and treatment in RT, it has become possible to apply higher doses to the tumor with fewer side effects. In addition, hypofractionation applications increase the fraction dose and decrease the total treatment time. Postoperative RT can also be applied in appropriate indication by looking at clinical and pathological features after surgery. The results of studies in metastatic disease and lymph node positive patients are promising. Studies are ongoing with the use of neoadjuvant or adjuvant chemotherapy, immunotherapy and next-generation hormotherapies in combination with RT.

\section{Acknowledgements}

Publication: The results of the study were not published in full or in part in form of abstracts.

Contribution: There is not any other contributors who may not be listed as authors.

Conflict of Interest: The authors have not declared any conflict of Interest.

Financial Disclosure: The authors have declared that they have not been granted any financial support.

\section{Ethics}

Informed Consent: All patients read the patient information form and written informed consents were obtained.

Peer-review: Externally peer-reviewed.

\section{Authorship Contributions}

Concept: I.A.Ç., Design: I.A.Ç., Data Collection and Processing: I.A.Ç., Analysis and Interpretation: I.A.Ç., Literature Search: I.A.Ç., Writing: İ.A.Ç.

\section{References}

1. Bortfeld TR. IMRT: a review and preview. Phys Med Biol 2006;51:363-379.

2. D'Amico AV, Whittington R, Malkowicz SB, et al. Biochemical outcome after radical prostatectomy, external beam radiation therapy or interstitial radiation therapy for clinically localized prostate cancer. JAMA 1998; 16:969-974. 
3. Merrick GS, Butler WM, Lief JH, Galbreath RW. Five-year biochemical outcome after prostate brachytherapy for hormone-naive men $<$ or $=$ 62years of age. Int J Radiat Oncol Biol Phys 2001;50:1253-1257.

4. Zelefsky MJ, Kuban DA, Levy LB, et al. Multi-institutional analysis of longterm outcome for stages T1-T2 prostate cancer treated with permanent seed implantation. Int J Radiat Oncol Biol Phys 2007;67:327-333.

5. Blasko JC, Grimm PD, Sylvester JE, et al. Palladium-103 brachytherapy for prostate carcinoma. Int J Radiat Oncol Biol Phys 2000;46:839-850.

6. Grimm PD, Blasko JC, Sylvester JE, et al. 10-year biochemical (prostatespecific antigen) control of prostate cancer with (125)I brachytherapy. Int J Radiat Oncol Biol Phys 2001;51:31-40.

7. Song MK, Unruh ML, Manatunga A, et al. SPIRIT trial: A phase III pragmatic trial of an advance care planning intervention in ESRD. Contemp Clin Trials 2018;64:188-194.

8. Donovan JL, Hamdy FC, Lane JA, et al. ProtecT Study Group. PatientReported Outcomes after Monitoring, Surgery, or Radiotherapy for Prostate Cancer. N Engl J Med 2016;375:1425-1437.

9. Dearnaley D, Syndikus I, Mossop H, et al. CHHiP Investigators Conventional versus hypofractionated high-dose intensity-modulated radiotherapy for prostate cancer: 5-year outcomes of the randomised, non-inferiority, phase 3 CHHiP trial. Lancet Oncol 2016;17:1047-1060.

10. Catton CN, Lukka H, Gu CS, et al. Randomized Trial of a Hypofractionated Radiation Regimen for the Treatment of Localized Prostate Cancer. J Clin Oncol 2017;35:1884-1890.

11. Lee WR, Dignam JJ, Amin MB, et al. Randomized Phase III Noninferiority Study Comparing Two Radiotherapy FractionationSchedules in Patients With Low-Risk Prostate Cancer. J Clin Oncol 2016;34:2325-2332.

12. Incrocci L, Wortel RC, Alemayehu WG, et al. Hypofractionated versus conventionally fractionated radiotherapy for patients with localized prostate cancer (HYPRO): final efficacy results from a randomized, multicenter, open-label, phase 3 trial. Lancet Oncol 2016;17:1061-1069.

13. Shaikh T, Li T, Handorf EA, et al. Long-Term Patient-Reported Outcomes From a Phase 3 Randomized Prospective Trial of Conventional Versus Hypofractionated Radiation Therapy for Localized Prostate Cancer. Int J Radiat Oncol Biol Phys 2017;97:722-731.

14. Hoffman KE, Voong KR, Levy LB, et al. Randomized Trial of Hypofractionated, Dose-Escalated, Intensity-Modulated Radiation Therapy (IMRT) Versus Conventionally Fractionated IMRT for Localized Prostate Cancer. J Clin Oncol 2018;36:2943-2949.

15. Valeriani $M$, Bonfili $P$, Reverberi $C$, et al. Moderate Hypofractionation in Patients with Low-risk Prostate Cancer: Long-term Outcomes. Anticancer Res 2018;38:1671-1676.

16. Datta NR, Stutz E, Rogers S, Bodis S. Conventional Versus Hypofractionated Radiation Therapy for Localized or Locally Advanced Prostate Cancer: A Systematic Review and Meta-analysis along with Therapeutic Implications. Int J Radiat Oncol Biol Phys 2017;99:573-589.

17. Morgan SC, Hoffman K, Loblaw DA, et al. Hypofractionated radiation therapy for located prostate cancer: An ASTRO, ASCO, and AUA evidencebased guideline. J Clin Oncol 2018;JCO:1801097.

18. Pham SG, Badiozamani K, Yao M, et al. Five-year Outcome of Stereotactic Hypofractionated Accurate Radiotherapy of the Prostate (SHARP) for Patients with Low-risk Prostate Cancer. Int J Radiat Oncol Biol Phys 2010;78:58.

19. Kupelian P, Katz AJ, Freeman D, et al. Long-term efficacy of stereotactic body radiotherapy for localized prostate cancer: A multi-institutional pooled analysis. J of clinical oncology 2018;36:86.

20. Mantz C. A Phase II Trial of Stereotactic Ablative Body Radiotherapy for Low-Risk Prostate Cancer Using a Non-Robotic Linear Accelerator and RealTime Target Tracking: Report of Toxicity, Quality of Life, and Disease Control Outcomes with 5-Year Minimum Follow-Up. Front Oncol 2014;4:279.

21. Hannan R, Tumati V, Xie XJ, et al. Stereotactic body radiation therapy for low and intermediate risk prostate cancer-Results from a multi-institutional clinical trial. Eur J Cancer 2016;59:142-151.

22. Musunuru HB, Quon H, Davidson M, et al. Dose-escalation of five-fraction SABR in prostate cancer: Toxicity comparison of two prospective trials. Radiother Oncol 2016;118:112-117.
23. Zimmermann M, Taussky D, Menkarios C, et al. Prospective Phase II Trial of Once-weekly Hypofractionated Radiation Therapy for Low-risk Adenocarcinoma of the Prostate: Late Toxicities and Outcomes. Clin Oncol (R Coll Radiol) 2016;28:386-392.

24. Widmark A, Gunnlaugsson A, Beckman L, et al. Ultra-hypofractionated versus conventionally fractionated radiotherapy for prostate cancer: 5-year outcomes of the HYPO-RT-PC randomised, non-inferiority, phase 3 trial. Lancet 2019;394:385-395.

25. Morrison K, Tree A, Khoo V, Van NJ. The PACE trial: International randomised study of laparoscopic prostatectomy vs. stereotactic body radiotherapy (SBRT) and standard radiotherapy vs. SBRT for early stage organ-confined prostate cancer. Journal of clinical Oncology 2018;36:26.

26. Jackson WC, Silva J, Hartman HE, et al. Stereotactic Body Radiation Therapy for Localized Prostate Cancer: A Systematic Review and Meta-Analysis of Over 6,000 Patients Treated On Prospective Studies. Int J Radiat Oncol Biol Phys 2019;104:778-789.

27. Dubray BM, Salleron J, Guerif SG, et al. Does short-term androgen depletion add to high dose radiotherapy ( $80 \mathrm{~Gy}$ ) in localized intermediate risk prostate cancer? Final analysis of GETUG 14 randomized trial (EU20503/NCT00104741). Journal of clinical Oncology 2016;20:5021.

28. Morris W], Tyldesley S, Rodda S, et al. Androgen Suppression Combined with Elective Nodal and Dose Escalated Radiation Therapy (the ASCENDERT Trial): An Analysis of Survival Endpoints for a Randomized Trial Comparing a Low-Dose-Rate Brachytherapy Boost to a Dose-Escalated External Beam Boost for High- and Intermediate-risk Prostate Cancer. Int J Radiat Oncol Biol Phys 2017;98:275-285.

29. Sathya JR, Davis IR, Julian JA, et al. Randomized trial comparing iridium implant plus external-beam radiation therapy with external-beam radiation therapy alone in node-negative locally advanced cancer of the prostate. I Clin Oncol 2005;23:1192-1199.

30. Hoskin PJ, Rojas AM, Bownes PJ, et al. Randomised trial of EBRT alone or combined with high-dose-rate brachytherapy boost for localised prostate cancer. Radiother Oncol 2012;103:217-222.

31. D'amico AV, Manola J, Loffredo $M$, et al. 6-month androgen suppression plus radiation therapy vs radiation therapy alone for patients with clinically localized prostate cancer: a randomized controlled trial. Jama 2004;292:821-827.

32. Pilepich M, Caplan R, Byhardt R, et al. Phase III trial of androgen suppression using goserelin in unfavorable-prognosis carcinoma of the prostate treated with definitive radiotherapy: report of Radiation Therapy Oncology Group Protocol 85-31. J Clin Oncol 1997; 15:1013-1021.

33. Bolla $M$, Collette $L$, Blank $L$, et al. Long-term results with immediate androgen suppression and external irradiation in patients with locally advanced prostate cancer (an EORTC study): a phase III randomised trial. The Lancet 2002;360:103-106.

34. Pilepich MV, Winter K, John MJ, et al. Phase III radiation therapy oncology group (RTOG) trial 86-10 of androgen deprivation adjuvant to definitive radiotherapy in locally advanced carcinoma of the prostate. Int J Radiat Oncol Biol Phys 2001;50:1243-1252.

35. Jones CU, Hunt D, McGowan DG, et al. Radiotherapy and short-term androgen deprivation For localized prostate cancer. N Engl J Med. 2011;365:107-118.

36. Bolla M, Maingon P, Carrie C, et al. Short androgen suppression and radiation dose escalation for intermediate-and high-risk localized prostate cancer: results of EORTC trial 22991. J Clin Oncol 2016;34:1748-1756.

37. Nabid A, Carrier N, Vigneault E, et al. A phase III trial of short-term androgen deprivation therapy in intermediate-risk prostate cancer treated with radiotherapy. J Clin Oncol 2015;33:5019.

38. Dearnaley DP, Jovic G, Syndikus I, et al. Escalated-dose versus control-dose conformal radiotherapy for prostate cancer: long-term results from the MRC RT01 randomised controlled trial. The Lancet Oncology 2014;15:464-473.

39. Bria E, Cuppone F, Giannarelli D, et al. Does hormone treatment added to radiotherapy improve outcome in locally advanced prostate cancer? MetaAnalysis of Randomized Trials. Cancer 2009;115:3446-3456.

40. Zietman AL, DeSilvio ML, Slater JD, et al. Comparison of conventionaldose vs high-dose conformal radiation therapy in clinically localized 
adenocarcinoma of the prostate: a randomized controlled trial. JAMA 2005;294:1233-1239.

41. Zapatero A, Guerrero A, Maldonado X, et al. High-dose radiotherapy with short-term or long-term androgen deprivation in localised prostate cancer (DART01/05 GICOR): a randomised, controlled, phase 3 trial. The Lancet Oncology 2015;16:320-327.

42. Network NCC. Prostate Cancer (Version 4. 2019). 2019; https://www. nccn.org/professionals/physician_gls/pdf/prostate.pdf.

43. Denham JW, Steigler A, Lamb DS, et al. Short-term neoadjuvant androgen deprivation and radiotherapy for locally advanced prostate cancer: 10year data from the TROG 96.01 randomised trial. The Lancet Oncology 2011;12:451-459.

44. Pisansky TM, Hunt D, Gomella LG, et al. Duration of androgen suppression before radiotherapy for localized prostate cancer: radiation therapy oncology group randomized clinical trial 9910. J Clin Oncol 2015;33:332-339.

45. Bolla M, De Reijke TM, Van Tienhoven $G$, et al. Duration of androgen suppression in the treatment of prostate cancer. $\mathrm{N}$ Engl J Med 2009;360:2516-2527.

46. Horwitz EM, Bae K, Hanks GE, et al. Ten-year follow-up of radiation therapy oncology group protocol 92-02: a phase III trial of the duration of elective androgen deprivation in locally advanced prostate cancer. J Clin Oncol 2008;26:2497-2504.

47. Denham JW, Joseph D, Lamb DS, et al. Short-term androgen suppression and radiotherapy versus intermediate-term androgen suppression and radiotherapy, with or without zoledronic acid, in men with locally advanced prostate cancer (TROG 03.04 RADAR): 10-year results from a randomised, phase 3, factorial trial. Lancet Oncol 2019;20:267-281.

48. Zapatero A, Guerrero A, Maldonado X, et al. Phase III trial comparing longterm versus short-term androgen deprivation combined with high-dose radiotherapy for localized prostate cancer: GICOR protocol DART01/05. Journal of Clinical Oncology 2011;29:4580.

49. Nabid A, Carrier N, Martin AG, et al. Duration of Androgen Deprivation Therapy in High-risk Prostate Cancer: A Randomized Phase III Trial. Eur Urol 2018;74:432-441.

50. Mahal BA, Yang DD, Wang NQ, et al. Clinical and Genomic Characterization of Low-Prostate-specific Antigen, High-grade Prostate Cancer. Eur Urol 2018;74:146-154.

51. Spratt DE, Zhang J, Santiago-Jiménez M, et al. Development and Validation of a Novel Integrated Clinical-Genomic Risk Group Classification for Localized Prostate Cancer. J Clin Oncol 2018;36:581-590.

52. Pisansky TM, Thompson IM, Valicenti RK, et al. Adjuvant and Salvage Radiation Therapy After Prostatectomy: ASTRO/AUA Guideline Amendment, Executive Summary 2018. Pract Radiat Oncol 2019;9:208-213.

53. Thompson IM, Tangen CM, Paradelo J, et al. Adjuvant radiotherapy for pathological T3NOMO prostate cancer significantly reduces risk of metastases and improves survival: long-term follow-up of a randomized clinical trial. J Urol 2009;181:956-962.

54. Dalela D, Santiago-Jiménez M, Yousefi K, et al. Genomic Classifier Augments the Role of Pathological Features in Identifying Optimal Candidates for Adjuvant Radiation therapy in Patients With Prostate Cancer: Development and Internal Validation of a Multivariable Prognostic Model J Clin Oncol 2017;35:1982-1990.

55. Shipley WU, Seiferheld W, Lukka HR, et al; NRG Oncology RTOG. Radiation with or without Antiandrogen Therapy in Recurrent Prostate Cancer. N Engl J Med 2017;376:417-428.

56. Carrie C, Hasbini A, de Laroche G, et al. Salvage radiotherapy with or without short-term hormone therapy for rising prostate- specific antigen concentration after radical prostatectomy (GETUG-AFU 16): randomised, multicentre, open-label phase 3 trial. Lancet Oncol 2016;17:747-756.
57. Abdollah F, Karnes RJ, Suardi N, et al. Impact of adjuvant radiotherapy on survival of patients with node-positive prostate cancer. J Clin Oncol 2014;32:3939-3947.

58. Ost P, Reynders D, Decaestecker K, et al. Surveillance or Metastasis-Directed Therapy for Oligometastatic Prostate Cancer Recurrence: A Prospective, Randomized, Multicenter Phase II Trial. J Clin Oncol 2018;36:446-453.

59. Parker CC, James ND, Brawley CD, et al. Systemic Therapy for Advanced or Metastatic Prostate cancer: Evaluation of Drug Efficacy (STAMPEDE) investigators. Radiotherapy to the primary tumour for newly diagnosed, metastatic prostate cancer (STAMPEDE): a randomised controlled phase 3 trial. Lancet 2018;392:2353-2366.

60. Boevé LMS, Hulshof MCCM, Vis AN, et al. Effect on Survival of Androgen Deprivation Therapy Alone Compared to Androgen Deprivation Therapy Combined with Concurrent Radiation Therapy to the Prostate in Patients with Primary Bone Metastatic Prostate Cancer in a Prospective Randomised Clinical Trial: Data from the HORRAD Trial. Eur Urol 2019;75:410-418.

61. Burdett S, Boevé LM, Ingleby FC, et al. Prostate Radiotherapy for Metastatic Hormone-sensitive Prostate Cancer: A STOPCAP Systematic Review and Meta-analysis. Eur Urol. 2019;76:115-124.

62. Rosenthal SA, Hu C, Sartor O, et al. Effect of Chemotherapy With Docetaxel With Androgen Suppression and Radiotherapy for Localized High-Risk Prostate Cancer: The Randomized Phase III NRG Oncology RTOG 0521 Trial. J Clin Oncol 2019;37:1159-1168.

\section{Questions}

\section{What are the treatment options for low risk prostate cancer?}
a. Brachytherapy
b. External beam radiotherapy
c. Hypofractionated radiotherapy
d. Stereotactic body radiotherapy
e. All of them

\section{Which of the following are not indications of postoperative radiotherapy?}
a. Positive surgical margin
b. pT3 tumor
c. p lymph node positivity
d. pT2 and surgical margin negativity
e. pT4 and seminal vesicle invasion

3. Which of the following is the standard radiotherapy treatment in high risk prostate cancer?

a. External beam radiotherapy +/- brachytherapy+ hormone therapy for 1-3 years

b. Stereotactic body radiotherapy

c. External beam radiotherapy

d. Brachytherapy

e. External beam radiotherapy + hormone therapy for 6 months 